\title{
Resistance of the Soybean Cultivar Archer to Pythium Damping-Off and Root Rot Caused by Several Pythium spp.
}

\author{
G. D. Bates, C. S. Rothrock, and J. C. Rupe, Department of Plant Pathology, University of Arkansas, Fayetteville, \\ 72701
}

\begin{abstract}
Bates, G. D., Rothrock, C. S., and Rupe, J. C. 2008. Resistance of the soybean cultivar Archer to Pythium damping-off and root rot caused by several Pythium spp. Plant Dis. 92:763-766.

Archer, a maturity group I soybean cultivar with demonstrated flood tolerance and resistance to Pythium ultimum, was compared with Hutcheson, a widely planted maturity group V cultivar in Arkansas, for resistance to $P$. ultimum, $P$. irregulare, $P$. aphanidermatum, $P$. vexans, and group HS. Emergence and establishment assays demonstrated that Archer had greater emergence and fewer disease symptoms after 10 days for all pathogenic species of Pythium than did Hutcheson. Archer also demonstrated higher root weights and fewer disease symptoms compared with Hutcheson in assays conducted for 6 weeks. Similar results were found using two different seed lots of the cultivars, suggesting that the results were not due to seed quality differences. This study indicates that resistance in Archer to Pythium damping-off and root rot compared with Hutcheson is robust, with efficacy over a number of Pythium spp. and a range of plant developmental stages.
\end{abstract}

During 2007, 1,255,000 ha were planted with soybean in Arkansas (15). The majority of those fields were alluvial soils with poor surface and subsurface drainage. Adequate soil drainage is essential for soybean production because temporary flooding and soil anoxia can reduce growth and yield of soybean plants compared with nonflooded conditions $(6,12-14)$.

Research by Kirkpatrick et al. (10) indicated that the isolation frequency of $P y$ thium spp. increased under soybean production subjected to temporary flooding at cracking (emergence) or at the V4 growth stage (4). Several species of Pythium were associated with soybean roots, including Pythium ultimum Trow, $P$. aphanidermatum (Edson) Fitzp., P. irregulare Buisman, $P$. vexans de Bary, $P$. oligandrum Drechsler, and group HS. Isolates in the group HS form hyphal swellings and lack oogonia (16). All species except $P$. oligandrum, a mycoparasite $(2,3)$, were reported as pathogenic on soybean $(10,18)$.

Greenhouse tests showed that Archer, a maturity group 1 cultivar with demonstrated flood tolerance (17), was significantly more resistant to $P$. ultimum than Hutcheson, a maturity group 5 cultivar commonly grown in Arkansas (9). Resis-

Corresponding author: C. S. Rothrock

E-mail: Rothrock@uark.edu

Published with the approval of the Director, Arkansas Experiment Station, Fayetteville.

Accepted for publication 5 January 2008.

doi:10.1094/PDIS-92-5-0763

(C) 2008 The American Phytopathological Society tance to Pythium spp. has rarely been reported in soybean and is not well underresistance for soybean have been observed using $P$. ultimum $(5,8,9)$.

The objective of this study was to compare the reaction of the soybean cvs. Archer and Hutcheson to pathogenic Pythium spp. known to colonize soybean in Arkansas over a range of growth stages.

\section{MATERIALS AND METHODS}

Inoculum. Isolates of Pythium were collected and identified by Dr. M. T. Kirkpatrick in 1999 from the Pine Tree Branch Experiment Station, near Colt, AR (10) and included P. ultimum (isolate 124), $P$. irregulare (isolates 115 and 21), $P$. aphanidermatum (isolates 88,64 , and 16), $P$. vexans (isolates 140 and 182), P. oligandrum (isolates 125 and 120), and group HS (isolates 126 and 117). Isolates are available from the authors. Group HS isolate 117 was identified as $P$. ultimum based on restriction fragment length polymorphism using the mitochondrial COX II gene and sequence of internal transcribed spacers 1 and 4 (L. Rosso, personal communication). Isolates were grown on cornmeal agar (CMA; Difco Laboratories, Detroit) and incubated at room temperature for 3 days. Six $1-\mathrm{cm}^{2}$ plugs of 3-day-old CMA cultures of each isolate were placed in 500-ml flasks containing $200 \mathrm{ml}$ of sand, $11.2 \mathrm{ml}$ of corn meal, and $80 \mathrm{ml}$ of deionized water that had been autoclaved for $40 \mathrm{~min}$ and then autoclaved again $24 \mathrm{~h}$ later. The isolates were allowed to colonize the sandcornmeal medium for 9 days. The flasks were shaken every other day to ensure uniform colonization. stood $(5,8)$. All reports of Pythium
To determine the inoculum density, $10 \mathrm{~g}$ of sand-corn meal inoculum of each isolate were placed in an Erlenmeyer flask containing $95 \mathrm{ml}$ of sterile distilled water and agitated on a wrist-action shaker for 20 min. Dilutions of $1 / 10$ and $1 / 100$ of original suspension were made and 1-ml portions of each were spread over the surface of five CMA plates. After 3 days, the number of Pythium colonies was counted and the number of propagules per gram of inoculum calculated.

Seed source. Seed of both Archer and Hutcheson were provided by D. Longer (University of Arkansas) and were produced in 1999 in a uniform environment at the Arkansas Agricultural Research and Extension Center in Fayetteville. Seed were harvested at approximately the same time and stored at $4^{\circ} \mathrm{C}$ until used. Germination at the start of the studies for both cultivars was $93 \%$ at $20^{\circ} \mathrm{C}$ by the rolled paper towel technique (1). To evaluate the influence of seed source on cultivar reaction, a seed lot assay was conducted using seed lots from 2001 of Archer from commercial seed from Minnesota and an Arkansas foundation seed lot of Hutcheson and the seed lots harvested in 1999.

Resistance assays. A Calloway silt loam soil obtained from the Pine Tree Branch Experiment Station near Colt, AR, was pasteurized for $30 \mathrm{~min}$ at $60^{\circ} \mathrm{C}$ prior to use for all experiments.

For emergence assays, a base layer of $250 \mathrm{~g}$ of pasteurized soil, oven dry weight equivalent (odw), followed by a layer of 12 $\mathrm{g}$ of Pythium inoculum, approximately 2 $\mathrm{mm}$ thick, were placed in Styrofoam cups $(11 \mathrm{~cm}$ in diameter by $8 \mathrm{~cm}$ high) with bottom drainage. Ten seeds then were placed directly onto the inoculum. The seeds then were covered with $20 \mathrm{~g}$ of pasteurized soil (odw). The cups were placed into $15-\mathrm{cm}$-diameter plastic watering trays with water to keep a constant matric potential of $-0.2 \mathrm{~J} / \mathrm{kg}$ at planting depth, based on water level. The cups were placed in a growth chamber at $20^{\circ} \mathrm{C}$ with a 12 -h photoperiod. The number of seedlings that emerged after 10 days was recorded. All seedlings and seed were separated from the soil and washed for 10 min under running water, and each seedling was rated for disease using a 0 -to-10 scale. The ratings represented percent root discoloration, with 0 equaling no discoloration and $1=1$ to $10,2=11$ to $20,3=21$ to $30,4=31$ to $40,5=41$ to $50,6=51$ to $60,7=61$ to 70 , 
$8=71$ to $80,9=81$ to 90 , and $10=91$ to100\% discoloration. Discoloration ratings were recorded for each seedling in a pot and were averaged for a pot using the midpercentile of each rating prior to analysis. All of the seeds or roots then were plated on $\mathrm{P}_{5} \mathrm{ARP}$ agar (7) to determine isolation frequency of Pythium spp. Each experiment consisted of five replications (cups) and this experiment was conducted five times.

An emergence assay was conducted to compare seed lots of Archer and Hutcheson using one species, P. aphanidermatum isolate 88 , by placing seed on a layer of inoculum utilizing the same methods and collecting the same data as described above. Each experiment consisted of four replicate cups with 10 seeds per cup. The experiment was conducted twice.

An establishment assay was conducted in a manner similar to the above experiments except, in this experiment, seed were placed on a noninfested layer about $1.8 \mathrm{~mm}$ thick $(10 \mathrm{~g})$ of pasteurized soil (odw) that was on top of the layer of inoculum. Removal of inoculum from direct contact with the seed allowed the root rot phase and plant growth to be examined, rather than emergence only. In addition to plant stand, disease rating, and Pythium spp. recovery, fresh root weight also was recorded in this assay. Each test consisted of three replicate cups with five seeds per cup. The experiment was conducted three times.

A long-term plant growth assay was conducted in pots constructed from PVC pipes (15 cm in diameter by $35 \mathrm{~cm}$ high) with a fiberglass screen on the bottom. A base layer of 4,000 $\mathrm{g}$ of pasteurized soil (odw) was covered with a layer of $20 \mathrm{~g}$ of Pythium sand-cornmeal inoculum, approximately $1.5 \mathrm{~mm}$ thick. The inoculum was covered with $20 \mathrm{~g}$ (odw) of pasteur- ized soil to provide a noninfested layer, similar to the establishment assay. Ten seeds were placed on this layer of soil and covered with $30 \mathrm{~g}$ of pasteurized soil. The pipes were placed into a 20 -cm-diameter plastic watering tray to keep a constant matric potential of $-0.5 \mathrm{~J} / \mathrm{kg}$ at planting depth based on water level. Plants were thinned to five representative plants per pipe at the V1 growth stage. The plants were grown in a greenhouse for 6 weeks at 20 to $30^{\circ} \mathrm{C}$. Data recorded included disease rating, fresh root weight, and Pythium spp. recovery. Each experiment consisted of five replications and the experiment was conducted two times.

Statistical analyses. All experiments used a randomized complete block design. A factorial treatment arrangement of the two cultivars and Pythium isolates was used when more than one isolate was examined. Data from the multiple experiments were combined and analyzed by GLM with SAS. Experiments were treated as random factors and interactions of experiment-treatment were used as the error term for comparing treatments to determine the repeatability of the experiments. The repeatability of experiments was determined to be not significant for each experiment type; therefore, experiments were combined. Means were separated using Fisher's protected least significant difference (LSD) at $P=0.05$.

\section{RESULTS}

Inoculum ranged from 820 to 1,340 propagules/g for isolates over all assays. For all experiments using a factorial treatment arrangement, there was a significant interaction between isolates and cultivars; thus, interaction means are presented for isolates and cultivars and LSDs were calculated to compare the appropriate interaction means. Plant stand was not signifi-

Table 1. Plant stand and disease rating of Archer and Hutcheson for the emergence assay ${ }^{\mathrm{x}}$

\begin{tabular}{|c|c|c|c|c|c|}
\hline \multirow[b]{2}{*}{ Pythium spp. } & \multirow[b]{2}{*}{ Isolate } & \multicolumn{2}{|c|}{ Plant stand ${ }^{y}$} & \multicolumn{2}{|c|}{ Disease rating $^{z}$} \\
\hline & & Archer & Hutcheson & Archer & Hutcheson \\
\hline \multirow[t]{3}{*}{ P. aphanidermatum } & 16 & $9.1 \mathrm{Ad}$ & $5.0 \mathrm{Bf}$ & 0.7 Bef & 2.9 Acd \\
\hline & 64 & $9.2 \mathrm{Acd}$ & $5.0 \mathrm{Bf}$ & $0.6 \mathrm{Bf}$ & 3.0 Acd \\
\hline & 88 & $9.2 \mathrm{Ad}$ & $5.2 \mathrm{Bf}$ & $0.4 \mathrm{Bf}$ & $2.9 \mathrm{Acd}$ \\
\hline \multirow{2}{*}{ Group HS } & 117 & 9.4 Abc & $6.1 \mathrm{Bd}$ & $2.0 \mathrm{Ba}$ & $3.2 \mathrm{Ac}$ \\
\hline & 126 & 9.4 Abc & $6.4 \mathrm{Bc}$ & $1.8 \mathrm{Bab}$ & 3.1 Acd \\
\hline \multirow[t]{2}{*}{ P. irregulare } & 21 & $9.5 \mathrm{Ab}$ & $3.6 \mathrm{Bg}$ & $1.6 \mathrm{Bbc}$ & $4.8 \mathrm{Aa}$ \\
\hline & 115 & $9.3 \mathrm{Acd}$ & $3.6 \mathrm{Bg}$ & $1.6 \mathrm{Bbc}$ & $4.8 \mathrm{Aa}$ \\
\hline \multirow[t]{2}{*}{ P. oligandrum } & 120 & $10.0 \mathrm{Aa}$ & $9.0 \mathrm{Ba}$ & $0.0 \mathrm{Ag}$ & $0.0 \mathrm{Ae}$ \\
\hline & 125 & $10.0 \mathrm{Aa}$ & $8.8 \mathrm{Ba}$ & $0.0 \mathrm{Ag}$ & $0.0 \mathrm{Ae}$ \\
\hline P. ultimum & 124 & $9.5 \mathrm{Ab}$ & $7.0 \mathrm{Bb}$ & $1.0 \mathrm{Bde}$ & $2.8 \mathrm{Ad}$ \\
\hline \multirow[t]{2}{*}{ P. vexans } & 140 & 9.4 Abc & $5.6 \mathrm{Be}$ & $1.1 \mathrm{Bd}$ & 4.6 Aab \\
\hline & 182 & $9.1 \mathrm{Ad}$ & $5.9 \mathrm{Bd}$ & $1.2 \mathrm{Bcd}$ & 4.4 Ab \\
\hline
\end{tabular}

${ }^{\mathrm{x}}$ Seed were placed in direct contact with an inoculum layer of Pythium isolates in pots and grown for 7 days at $20^{\circ} \mathrm{C}$. Means represent five combined experiments with five replications. Cultivars for a Pythium isolate did not significantly differ if followed by the same capital letter, protected least significant difference (LSD; $P=0.05$ ). Within a cultivar, Pythium isolates did not significantly differ if followed by the same lower-case letter, protected LSD $(P=0.05)$.

y Plant stand from 10 seeds planted.

${ }^{\mathrm{z}}$ Disease rating based on scale of 0 to 10 , where $0=$ healthy and $1=1$ to $10,2=11$ to $20,3=21$ to $30,4=31$ to $40,5=41$ to $50,6=51$ to $60,7=61$ to $70,8=71$ to $80,9=81$ to 90 , and $10=91$ to $100 \%$ root discoloration.

cantly different for the pathogenic Pythium spp. compared with $P$ oligandrum for Archer, and ranged from 9.1 to 10 seedlings emerged from the 10 seeds that were planted. Plant stands for Hutcheson were reduced significantly from 8.8 plants for soils infested with $P$. oligandrum to 3.6 for $P$. irregulare (Table 1). Isolates of $P$. aphanidermatum, $P$. vexans, and $P$. irregulare caused the greatest stand reduction at $20^{\circ} \mathrm{C}$ compared with the isolates of the other Pythium spp. examined. Root discoloration was statistically higher for Hutcheson for all potentially pathogenic isolates compared with Archer (Table 1). Disease rating for Archer ranged from 0 for $P$. oligandrum to 2.0 in group HS. For Hutcheson, disease rating ranged from 0 for $P$. oligandrum to 4.8 for $P$. irregulare. Disease ratings were significantly lower for $P$. oligandrum than all other species in both Archer and Hutcheson. The Pythium sp. used to infest each soil was recovered from all plated plants of that treatment (data not shown).

The seed lot emergence assay demonstrated that there were no significant differences between seed lots for a cultivar for stand or root discoloration. However, there were significant differences between cultivars. Archer had a plant stand of 9.1 for the 2001 seed lot and 8.9 for the 1999 seed lot, with a disease rating of 0.5 for both seed lots. Hutcheson had a plant stand of 3.1 for the 2001 seed lot and 2.9 for the 1999 seed lot, with disease ratings of 2.8 for the 2001 seed lot and 2.5 for the 1999 seed lot. Both seed lots of Archer demonstrated statistically higher stand than either seed lot of Hutcheson $(P=0.05)$. Root discoloration for Hutcheson was statistically higher than Archer $(P=0.05)$. $P y$ thium spp. were recovered from all plated plants.

For the establishment assay, where seed were separated from inoculum by a layer of noninfested pasteurized soil, plant stand was high and statistically the same between the two cultivars, except for isolate 126 of group HS, where Hutcheson had a significantly lower stand than Archer (Table 2). Within Hutcheson, there were statistical differences for root discoloration among isolates within a given species for $P$. vexans, $P$. aphanidermatum, and group HS. There were significantly higher disease ratings in Hutcheson compared with Archer for all species except $P$. oligandrum (Table 2). Root weights were reduced significantly for Hutcheson compared with Archer for $P$. aphanidermatum isolate 88 and group HS isolate 126. Isolates of all pathogenic species did not reduce root weight in Archer compared with the isolates of $P$. oligandrum. Isolates for group HS, P. ultimum, and P. vexans isolate 140 significantly reduced root weight for Hutcheson compared with isolates of $P$. oligandrum. Pythium spp. were recovered from all plated plants. 
In the plant development assay, Hutcheson had significantly higher root discoloration than Archer for all isolates of pathogenic Pythium spp. (Table 3). Archer had the most root discoloration with isolates of $P$. irregulare followed by $P$. ultimum and $P$. vexans. Isolates of the other species were not significantly different from $P$. oligandrum. Hutcheson had the most root discoloration with isolates of $P$. vexans, followed by group HS, $P$. aphanidermatum, $P$. irregulare, and then $P$. ultimum. All species caused significantly more root discoloration than P. oligandrum for Hutcheson (Table 3). Isolates of a given species reacted similarly.

Root weight in soil infested with isolates of $P$. oligandrum was greater for Hutcheson than Archer (Table 3). However, when soil was infested with isolates of pathogenic species, root weights were significantly less for Hutcheson compared with Archer for isolate 16 of $P$ aphanidermatum and all isolates of group HS, $P$. irregulare, $P$. ultimum, and $P$. vexans. All species reduced root weight in both cultivars when compared with $P$. oligandrum, except for $P$. vexans for cv. Archer. Both Archer and Hutcheson demonstrated the lowest numerical root weight with $P$. ultimum. Pythium spp. were recovered from all plated plants.

\section{DISCUSSION}

Archer was resistant to $P$. ultimum, $P$. aphanidermatum, $P$. irregulare, $P$. vexans, and group HS isolates compared with Hutcheson in the emergence assay, as well as establishment and plant growth assays, indicating that the resistance in Archer is robust over numerous Pythium spp. and over a range of plant development stages. Resistance was demonstrated in Archer as greater plant stand and less root discoloration compared with Hutcheson. Isolates showed some variation against the cultivars in the assays, especially Hutcheson in the establishment assay. The variation among isolates against Hutcheson suggests some differences in aggressiveness of isolates within a species. However, these differences were minor compared with differences among species. In the plant growth assay, which was conducted over 6 weeks, differences between a maturity group I and a maturity group $\mathrm{V}$ cultivar seemed to play a larger role than in the seedling assays. Hutcheson was still growing vigorously and vegetatively at the end of 6 weeks, while Archer was setting pods. Thus, root weight for Hutcheson was much greater at 6 weeks than Archer in soil infested with $P$. oligandrum. However, Hutcheson root weight decreased dramatically in soil infested with any isolate of a pathogenic Pythium spp. compared with Archer in this longer assay, again demonstrating Archer's resistance.

$P$. oligandrum, reported to be a mycoparasite $(2,3)$, worked effectively as a con- trol. P. oligandrum frequently is associated with soybean roots in the field (10). In experiments where noncolonized sandcornmeal also was used as a control, $P$. oligandrum had less variation than noninfested soil, with noncolonized sandcornmeal medium negatively affecting plant growth in some cases (data not shown). This nutrient source in the control may have led to greater variation because of microbial activity or compounds in the medium affecting plant growth.

This research demonstrated that, for the isolates and the Pythium spp. examined, Archer is more resistant than Hutcheson to Pythium damping-off and root rot. Differences in virulence were evident among species. $P$. irregulare, $P$. vexans, and $P$. aphanidermatum appeared to be more important than P. ultimum and group HS in the seed rot and preemergent phases of the disease. P. ultimum and group HS demonstrated increasing virulence in the root rot

Table 3. Root discoloration and fresh root weight of Archer and Hutcheson for the plant growth assay ${ }^{y}$

\begin{tabular}{|c|c|c|c|c|c|}
\hline \multirow[b]{2}{*}{ Pythium spp. } & \multirow[b]{2}{*}{ Isolate } & \multicolumn{2}{|c|}{ Root discoloration $^{z}$} & \multicolumn{2}{|c|}{ Fresh root weight (g) } \\
\hline & & Archer & Hutcheson & Archer & Hutcheson \\
\hline \multirow[t]{3}{*}{ P. aphanidermatum } & 16 & $0.0 \mathrm{Bc}$ & $4.5 \mathrm{Ac}$ & $4.6 \mathrm{Ac}$ & $3.0 \mathrm{Bb}$ \\
\hline & 64 & $0.1 \mathrm{Bc}$ & $4.3 \mathrm{Ac}$ & $4.5 \mathrm{Ac}$ & $3.1 \mathrm{Ab}$ \\
\hline & 88 & $0.0 \mathrm{Bc}$ & $4.1 \mathrm{Ac}$ & $4.5 \mathrm{Ac}$ & $3.1 \mathrm{Ab}$ \\
\hline \multirow[t]{2}{*}{ Group HS } & 117 & $0.0 \mathrm{Bc}$ & $5.8 \mathrm{Ab}$ & $9.2 \mathrm{Ab}$ & $2.6 \mathrm{Bb}$ \\
\hline & 126 & $0.0 \mathrm{Bc}$ & $6.0 \mathrm{Ab}$ & $8.9 \mathrm{Ab}$ & $2.4 \mathrm{Bbc}$ \\
\hline \multirow[t]{2}{*}{ P. irregulare } & 21 & $1.6 \mathrm{Ba}$ & $4.6 \mathrm{Ac}$ & $4.1 \mathrm{Ac}$ & $2.3 \mathrm{Bbc}$ \\
\hline & 115 & $1.5 \mathrm{Ba}$ & $4.2 \mathrm{Ac}$ & $4.0 \mathrm{Ac}$ & $2.4 \mathrm{Bbc}$ \\
\hline \multirow[t]{2}{*}{ P. oligandrum } & 120 & $0.0 \mathrm{Ac}$ & $0.0 \mathrm{Ae}$ & $20.8 \mathrm{Ba}$ & $40.9 \mathrm{Aa}$ \\
\hline & 125 & $0.0 \mathrm{Ac}$ & $0.0 \mathrm{Ae}$ & $20.6 \mathrm{Ba}$ & $40.1 \mathrm{Aa}$ \\
\hline P. ultimum & 124 & $1.0 \mathrm{Bb}$ & $3.2 \mathrm{Ad}$ & $2.2 \mathrm{Ac}$ & $1.6 \mathrm{Bc}$ \\
\hline \multirow[t]{2}{*}{ P. vexans } & 140 & $0.9 \mathrm{Bb}$ & 6.1 Aab & $21.8 \mathrm{Aa}$ & $2.4 \mathrm{Bbc}$ \\
\hline & 182 & $0.9 \mathrm{Bb}$ & $6.6 \mathrm{Aa}$ & $21.4 \mathrm{Aa}$ & $2.4 \mathrm{Bbc}$ \\
\hline
\end{tabular}

${ }^{\mathrm{y}}$ Inoculum was separated from seeds in pots by a layer of pasteurized soil. The experiment was terminated after 6 weeks. Means represent two combined experiments with five replications. Each pot was thinned to five plants. Cultivars for a Pythium isolate did not differ significantly if followed by the same capital letter, protected least significant difference (LSD; $P=0.05$ ). Within a cultivar, Pythium isolates did not differ significantly if followed by the same lower-case letter, protected LSD $(P=0.05)$.

${ }^{\mathrm{z}}$ Disease rating based on scale of 0 to 10 , where $0=$ healthy and $1=1$ to $10,2=11$ to $20,3=21$ to $30,4=31$ to $40,5=41$ to $50,6=51$ to $60,7=61$ to $70,8=71$ to $80,9=81$ to 90 , and $10=91$ to $100 \%$ root discoloration.

Table 2. Plant stand, disease rating, and root weight of Archer and Hutcheson in the establishment assay ${ }^{\mathrm{x}}$

\begin{tabular}{|c|c|c|c|c|c|c|c|}
\hline \multirow[b]{2}{*}{ Pythium spp. } & \multirow[b]{2}{*}{ Isolate } & \multicolumn{2}{|c|}{ Plant stand ${ }^{y}$} & \multicolumn{2}{|c|}{ Disease rating $^{\mathrm{z}}$} & \multicolumn{2}{|c|}{ Fresh root weight (g) } \\
\hline & & Archer & Hutcheson & Archer & Hutcheson & Archer & Hutcheson \\
\hline \multirow[t]{3}{*}{ P. aphanidermatum } & 16 & $4.3 \mathrm{Aa}$ & $3.4 \mathrm{Abc}$ & 1.4 Bde & $3.8 \mathrm{Abc}$ & $2.3 \mathrm{Ab}$ & $1.8 \mathrm{Aabc}$ \\
\hline & 64 & $4.2 \mathrm{Aa}$ & $4.7 \mathrm{Aa}$ & $1.8 \mathrm{Bbcd}$ & $4.5 \mathrm{Ab}$ & $2.0 \mathrm{Ab}$ & $1.9 \mathrm{Aabc}$ \\
\hline & 88 & $4.6 \mathrm{Aa}$ & 4.0 Aabc & $1.9 \mathrm{Bbcd}$ & $3.6 \mathrm{Ac}$ & 2.6 Aab & $1.8 \mathrm{Babc}$ \\
\hline \multirow[t]{2}{*}{ Group HS } & 117 & $4.2 \mathrm{Aa}$ & 4.3 Aab & $2.2 \mathrm{Bbc}$ & 6.6 Aa & $1.9 \mathrm{Ab}$ & $1.5 \mathrm{Abc}$ \\
\hline & 126 & $4.4 \mathrm{Aa}$ & $3.1 \mathrm{Bc}$ & $1.6 \mathrm{Bcde}$ & $4.7 \mathrm{Ab}$ & $2.5 \mathrm{Aab}$ & $1.4 \mathrm{Bbc}$ \\
\hline \multirow[t]{2}{*}{ P. irregulare } & 21 & $4.6 \mathrm{Aa}$ & 4.2 Aab & 1.1 Bef & $3.2 \mathrm{Ac}$ & $2.0 \mathrm{Ab}$ & $2.0 \mathrm{Aab}$ \\
\hline & 115 & $4.3 \mathrm{Aa}$ & $4.3 \mathrm{Aab}$ & 1.1 Bef & $3.4 \mathrm{Ac}$ & $2.4 \mathrm{Ab}$ & $2.0 \mathrm{Aab}$ \\
\hline \multirow{2}{*}{ P. oligandrum } & 120 & $4.6 \mathrm{Aa}$ & 4.4 Aab & $0.2 \mathrm{Ag}$ & $0.3 \mathrm{Ad}$ & $2.8 \mathrm{Aa}$ & $2.3 \mathrm{Aa}$ \\
\hline & 125 & $4.7 \mathrm{Aa}$ & $4.6 \mathrm{Aa}$ & $0.6 \mathrm{Afg}$ & $0.4 \mathrm{Ad}$ & $2.1 \mathrm{Ab}$ & $2.3 \mathrm{Aa}$ \\
\hline P. ultimum & 124 & $4.6 \mathrm{Aa}$ & $3.4 \mathrm{Abc}$ & $1.9 \mathrm{Bbcd}$ & 7.1 Aa & $1.8 \mathrm{Ab}$ & $1.3 \mathrm{Ac}$ \\
\hline \multirow[t]{2}{*}{ P. vexans } & 140 & 4.6 Aa & 4.1 Aabc & $2.3 \mathrm{Bab}$ & $6.5 \mathrm{Aa}$ & $1.9 \mathrm{Ab}$ & $1.4 \mathrm{Abc}$ \\
\hline & 182 & $4.2 \mathrm{Aa}$ & 4.4 Aab & $2.9 \mathrm{Ba}$ & $4.1 \mathrm{Abc}$ & $1.9 \mathrm{Ab}$ & 1.7 Aabc \\
\hline
\end{tabular}

${ }^{\mathrm{x}}$ Inoculum was separated from seeds in pots by a layer of pasteurized soil. Means represent three combined experiments with three replications. The experiment was conducted at $20^{\circ} \mathrm{C}$ for 10 days. Cultivars for a Pythium isolate did not differ significantly if followed by the same capital letter, protected least significant difference (LSD; $P=0.05$ ). Within a cultivar, Pythium isolates did not differ significantly if followed by the same lower-case letter, protected $\operatorname{LSD}(P=0.05)$.

${ }^{\mathrm{y}}$ Plant stand from 5 seeds planted.

${ }^{\mathrm{z}}$ Disease rating based on scale of 0 to 10 , where $0=$ healthy and $1=1$ to $10,2=11$ to $20,3=21$ to $30,4=31$ to $40,5=41$ to $50,6=51$ to $60,7=61$ to 70 , $8=71$ to $80,9=81$ to 90 , and $10=91$ to $100 \%$ root discoloration. 
phase of the disease. In addition to root discoloration, isolates of pathogenic $P y$ thium spp. caused dramatic reductions in root weight in the plant growth assay, in some cases in the absence of appreciable root discoloration. It appears that, by colonizing primarily juvenile tissue near the root tips or by causing sloughing off of cortical tissue as the root matures over the 6 weeks of this assay, much of the damage from Pythium root rot was not associated with root rot symptoms. Seed lot was not a factor in the resistance observed with Archer, indicating that differences in disease reaction between cultivars were not due to differences in seed quality. Nanayakkara (11) also demonstrated the consistency of resistance in Archer compared with Hutcheson using artificially deteriorated seed.

The relationship between inheritance of Pythium resistance in Archer and its reported flood tolerance is unknown. Characterization or identification of the nature of the resistance would aid in breeding because other more adapted genotypes or cultivars may have this resistance. The nature of other cultivars believed to have resistance to Pythium spp. such as Dare, V81-141, (5), and Semmes (8) should be compared with Archer.

\section{ACKNOWLEDGMENTS}

This research was funded in part by the Arkansas Soybean Promotion Board. We thank R. W.
McNew, Agricultural Statistics Laboratory, University of Arkansas, Fayetteville, for his assistance with the statistical analysis for this research project.

\section{LITERATURE CITED}

1. AOSA (Association of Official Seed Analysts). 1983. Seed vigor testing handbook. AOSA Publ. No. 32.

2. Benhamou, N., Rey, P., Cherif, M., Hockenhull, J., and Tirilly, Y. 1997. Treatment with the mycoparasite Pythium oligandrum triggers induction of defense related reactions in tomato roots when challenged with Fusarium oxysporum f. sp. radicis-lycopersici. Phytopathology 87:108-122.

3. Deacon, J. 2000. The Microbial World: Pythium oligandrum and other mycoparasites. University of Edinburgh. Published online.

4. Fehr, W. R., Caviness, C. E., Burmood, D. T., and Pennington, J. S. 1971. Stage of development descriptions for soybeans Glycine max (L.) Merr. Crop. Sci. 11:929-931.

5. Griffin, G. J. 1990. Importance of Pythium ultimum in a disease syndrome of cv. Essex soybean. Can. J. Plant Pathol. 12:135-140.

6. Heatherly, L. G., and Pringle, H. C. 1991. Soybean cultivars response to flood irrigation of clay soil. Agron. J. 83:231-236.

7. Jeffers, S. N., and Martin, S. B. 1986. Comparison of two media selective for Phytophthora and Pythium species. Plant Dis. 70:1038-1043.

8. Keeling, B. L. 1974. Soybean seed rot and the relation of seed exudate to host susceptibility. Phytopathology 64:1445-1447.

9. Kirkpatrick, M. T., Rothrock, C. S., Rupe, J. C., and Gbur, E. E. 2006. The effect of $P y$ thium ultimum and soil flooding on two soy- bean cultivars. Plant Dis. 90:597-602.

10. Kirkpatrick, M. T., Rupe, J. C., and Rothrock, C. S. 2006. Soybean response to flooded soil conditions and the association with soilborne plant pathogenic genera. Plant Dis. 90:592596.

11. Nanayakkara, R. 2001. Influence of soybean cultivar, seed quality, and temperature on seed exudation and Pythium disease development. Ph.D. dissertation, University of Arkansas, Fayetteville.

12. Oosterhuis, D. M., Scott, H. D., Hampton, R. E., and Wullschleger, S. D. 1990. Physiological responses of two soybean cultivars to short-term flooding. Environ. Exp. Bot. 30:85-92.

13. Russell, D. A., Wong, D. L., and Sachs, M. M. 1990. The anaerobic response of soybean Plant Physiol. 92:401-407.

14. Scott, H. D., DeAngulo, J., Daniels, M. B., and Wood, L. S. 1989. Flood duration effects on soybean growth and yield. Agron. J. 81:631636.

15. Soy Stats Online. 2006. Soybean Area Planted by State. Published online. http://www.soy stats.com/2007/Default-frames.htm.

16. Van der Plaats-Niterink, A. J. 1981. Monograph of the genus Pythium. Studies in Mycology No. 21. Centraalbureau Voor Schimmelculutres, Baarn, the Netherlands.

17. VanToai, T., St. Martin, S., Chase, K., Boru, G., Schnipke, V., Schmitthenner, A. F., and Lark. K. 2001. Identification of a QTL Associated with tolerance of soybean to soil waterlogging. Crop Sci. 41:1247-1252.

18. Yang, X. B. 1999. Pythium damping-off and root rot. Pages 42-44 in: Compendium of Soybean Diseases. G. L. Hartman, J. B. Sinclair, and J. C. Rupe, eds. American Phytopathological Society Press, St. Paul, MN. 